\title{
The knowledge of the spatial-temporal rainfall patterns as a tool for storm-design. Case study: Manizales, Colombia
}

\author{
Victor Delgado ${ }^{1}$, Jeannette Zambrano ${ }^{1}$, and Jorge Vélez ${ }^{1}$ \\ ${ }^{1}$ Universidad Nacional de Colombia Sede Manizales
}

May 11, 2020

\begin{abstract}
Climatic variability in the Andean regions of Colombia is high, both spatially and temporally. It should be analyzed in the short and long term, depending on the information available. This type of spatio-temporal analysis generates tools for environmental planning and management in urban areas. Given the high complexity of the meteorological processes that occur in the Andean region and in the tropics, these must be studied, understood and disseminated. This research focuses on a diagnosis of the diurnal cycle, the analysis of the monthly structure of precipitation and rain events, based on information collected from ground stations located in the city of Manizales, Caldas (Colombia), which contributes to the estimation of the city's design storm. Results show a strong influence of the Intertropical Confluence Zone (ITCZ) on intra-annual city rain behavior: intra-daily, there are significant variations in precipitation across the city; and throughout the day, it rains the least in the morning and the most at night. Recorded rain events are intense, with average durations of 20 minutes, confirming the high spatial-temporal variability. The dimensionless pattern of the observed rainstorms are the basis for the design storm for the city's hydraulic infrastructures.
\end{abstract}

Keywords: Precipitation diurnal cycle; monthly cycle; storm design; Rainfall patterns; spatiotemporal analysis; Tropical Andean cities; Short term precipitation; environmental planning INTRODUCTION

There is a high spatial and temporal climatic variability in the Andean regions of Colombia, and it can be analyzed in the short term, when the information dates only a few years back, or the long term, when information for a longer period is available. Both types of analysis allow characterizing and knowing the patterns of climatic variables in space and time (Martínez \& Salas, 2015). Knowing the spatio-temporal variability of the main climatic variables on its intra-daily and intra-annual scale in a tropical Andean city is an urban planning tool that strengthens decision-making. Precipitation is fundamental since it directly defines the water supply or availability and is considered one of the most important mechanisms in the global hydrological cycle (Marín et al., 2005). Therefore, knowing this variability becomes a water heritage management tool, where its proper management involves agricultural practices, human and hydroelectric consumption, the ecosystems, and other industrial or mining uses. Proper management and planning thus require implementing actions that minimize the impact of water use, so it is necessary to analyze and detect historical modifications on the spatial and temporal characteristics and behaviors of the pluviometric regime (Puertas, Carvajal, \& Quintero, 2011).

Understanding the diurnal rain cycle is important in the short term for many reasons: the main one is because the amplitude and phase of this cycle are the result of the interaction between dynamic and radiative processes. The successful explanation of such processes is a useful measure to make sense of atmospheric physics at these time scales (Zuluaga, Poveda, \& Mejia, 2004), which allows understanding regional patterns of climate behavior. This knowledge is basic for the physical parameterization of climate models (Gui-Ying 
\& Slingo, 2001). Some factors that directly affect local atmospheric dynamics and cause changes in diurnal precipitation cycles are orography, relative humidity and thermodynamic processes (Poveda et al., 2002). Due to its importance, the diurnal cycle of precipitation has been studied for a long time (Albright, Mock, Recker, \& Reed, 1981; Gray \& Jacobson, 1977; McGarry \& Reed, 1978). In Colombia, precipitation has been extensively studied on monthly or longer periods, while the daytime cycle has been little studied due to the scarce information available from ground stations until relatively recently. The studies carried out to date (Bedoya-Soto, Aristizábal, Carmona, \& Poveda, 2019; Mapes, Warner, Xu, \& Negri, 2003a, 2003b; Poveda et al., 2005; Snow, 1976; Suárez-Cobián, 1959; Trewartha, 1981; Trojer, 1959; Zuluaga et al., 2004) have allowed to recognize fixed patterns as a bimodal behavior in the diurnal cycle of precipitation in the western zone of the central mountain range of Colombia, with peaks in the afternoon and towards midnight, driest periods between 9:00 - 11:00 h, and highly variable cycles between contiguous stations.

To make up for the lack of ground stations that allow such research to be carried out, the latest studies have concentrated on the use of satellite or radar information on both cloudiness and precipitation. Thus, studies regarding the frequency, intensity and diurnal cycle of rain use satellite information from different sources, such as CMORPH (Climate Prediction Center Morphing technique), PERSIANN (Precipitation Estimation from Remotely Sensed Information using Artificial Neural Networks), TRMM3B42 (Tropical Rainfall Measuring Mission daily and sub-daily (3hr) averages precipitation), which in turn have been compared to ground records. The results indicate that the spatial distribution is comparable on monthly scales, yet diurnal scales deviate in up to $30 \%$ (Dai, Lin, \& Hsu, 2007). Rozante et al. (2018) reach similar conclusions, identifying that the satellites Itegrated Multi-satellite Retrievals for Global Precipitation Measurement (IMERG) and Global Satellite Mapping of Precipitation (GSMap) overestimate diurnal rainfall in northern Brazil when compared to TRMM, reason why they conclude that the GSMaP satellite could replace the TRMM which will soon go out of orbit (Rozante, Vila, Barboza Chiquetto, Fernandes, \& Souza Alvim, 2018). Most of these studies have concluded that, in the tropics, maximum convection or precipitation tends to occur late at night or in the early morning (Gui-Ying \& Slingo, 2001).

Finally, the intra-hourly distribution of precipitation is analyzed by means of a frequency analysis. The temporal distribution of events is important because it has been established that the hydrological response and the maximum peak of runoff flow depend directly on the maximum intensity of precipitation (Adams \& Howard, 1986; Ball, 1994; El-Jabi \& Sarraf, 1991; V. P. Singh, 1997; Šraj, Dirnbek, \& Brilly, 2010). Therefore, adequately estimating the design storm allows to obtain design floods for hydraulic infrastructure. Design storms must be based on the dimensionless shapes observed in each particular region, which is why their analysis has been widely carried out in the USA (Chow, Maidment, \& Mays, 1994) and in different parts of the world using the data from the registers, in order to replicate design storms for hydraulic infrastructures (Azli \& Rao, 2010; Huff, 1967; S. C. Singh et al., 2017).

This research aims to characterize the rain events and the diurnal cycle of precipitation in the city of Manizales, a tropical Andean city, taking into account the hydrometeorological 2010-2018 data of the city stations of the network of the Risk Management Unit (IDEA UN Manizales \& CORPOCALDAS, 2015), a network that belongs to the Caldas Integrated Environmental Monitoring System (SIMAC because of its name in Spanish), where an effort is being made to improve meteorological information that allows for this type of analysis. The SIMAC is a recent system and, although it now has 124 installed hydrometeorological stations, only 13 of these stations allow simultaneous analysis of the last 9 years. It is very important to highlight that the interannual and multiannual analysis of climate variability and climate change was not performed, basically because there are not yet long enough series for a complete and detailed analysis of this type of variability within Manizales. This analysis is still relevant given its contribution to the knowledge of short-term temporal-spatial variability in the city.

\section{MATERIALS AND METHODS}




\subsection{Study area}

The study was carried out in the city of Manizales, capital of the department of Caldas, located in the central region of western Colombia, on the extension of the Andes. Manizales has its own mountain characteristics such as average slopes of $25 \%$ and an average altitude of 2,153 meters above sea level. Thanks to its geographical location, Manizales has a bimodal climate: each year there are two seasons of high rainfall and two of low rainfall (Vélez-Upegui, Duque-Méndez, Mejía-Fernández, \& Orozco-Alzate, 2012). Due to its geographical location and due to its orography of great slopes, Manizales is home to snow-capped mountains, forests, mountains and valleys, making the relief of the city especially mountainous. The city has eight microclimates in its urban area with an average temperature of $18^{\circ} \mathrm{C}$. During the rainiest months, the precipitation reaches values between 100 and $500 \mathrm{~mm}$, while during the least rainy months, the precipitation varies between 50 and $300 \mathrm{~mm}$ (Velez-Upegui et al., 2012). The two annual low rainy seasons begin with the solstices on June 22 and December 21, and the two high rainy seasons begin with the equinoxes on March 21 and September 22.

12 meteorological stations and a hydrometeorological station were used, distributed in the urban area of Manizales (Figure 1), which belong to the network for risk management due to landslides that measure rainfall every five minutes and which are managed by the Universidad Nacional de Colombia in Manizales. The information is available in a data warehouse called the Caldas Environmental Data and Information Center (CDIAC by its name in Spanish) (IDEA UN Manizales \& CORPOCALDAS, 2015). The oldest station was installed in 2002. The common period between the stations analyzed is 2010-2018 for the analysis of the day cycle, however, the 2006-2014 period was used for event analysis of the events. It is not possible to carry out longer-term studies, such as an extreme frequency or climatic variability analysis, with the data available, so these were not included.

Figure 1 . Location of the city of Manizales and location of the hydrometeorological stations

\section{Methodology}

The information downloaded from the CDIAC was analyzed (http://cdiac.manizales.unal.edu.co/inicio/). Filters were used to correct and depurate the data: those outside the sensor measurement ranges, or known physical ranges, and those with significant differences in the continuity of the records according to the precipitation values were specifically eliminated, while measurement errors sensors were reviewed. Finally, data consistency and homogeneity were analyzed, obtaining the records from Table 1. The consistency analysis was carried out using an accumulated double mass analysis, accumulating the diurnal rains from each of the stations and graphing them with each other. Higher slopes were found in comparison with El Carmen; smoother slopes when compared with La Palma, Bosques del Norte and Aranjuez; while Posgrados and Emas were identified within an intermediate group. For Yarumos, the beginning is similar to the rainiest parts of the city, but the final part has a slope more similar to the less rainy areas. The discontinuity in the slopes is explained by missing data or because the origin of the rains is different. The homogeneity analysis was performed using statistical tests that measure changes in mean and variance. For diurnal rainfall, the use of consistency analysis is considered appropriate.

Table 1. Summary of precipitation records for network stations for landslide risk management in the city of Manizales

Once these analyzes were carried out and based in the precipitation data with a five-minute temporal resolution $\mathrm{P}_{\mathrm{i}}$, the hourly values $\mathrm{P}_{\mathrm{mha}}$ were obtained, from which the monthly mean values were obtained for each hour $\mathrm{h}$ of each year $\mathrm{a}, \mathrm{m}(\mathrm{m}=1, \ldots, 12)$, $\mathrm{a}(\mathrm{a}=1, \ldots, \mathrm{na})$ averaging the values of every day of the year for each hour (Eq. 1).

\begin{tabular}{|c|c|}
\hline $\mathrm{Phma}=\frac{1}{365} \sum_{d=1}^{365} \mathrm{Phma}_{d}$ & $\mathrm{Phma}=\frac{1}{\mathrm{na}} \sum_{a=1}^{\mathrm{na}} \mathrm{Phm}_{a}$ \\
\hline
\end{tabular}


With these values, the multi-year monthly hourly mean values were obtained, as the average of the previous values for all years a of the period analyzed $(\mathrm{a}=1, \ldots, \mathrm{na})$.

$\overline{\mathrm{Phm}=\frac{1}{9} \sum_{a=1}^{9} \mathrm{Phma}_{a} \quad 2}$

The monthly means for each year were obtained as the average of the hourly mean values of each month, averaging all the hours of each month.

$$
\overline{\mathrm{Pma}=\frac{1}{24} \sum_{h=1}^{24} \mathrm{Phma}_{h} \quad 3}
$$

The multi-year monthly mean values were obtained as the average of the monthly values of each year $(a=$ $1, \ldots$, na).

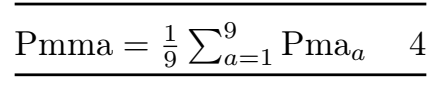

Likewise, the relative hourly frequency of precipitation was obtained as the amount of relative precipitation at each hour.

$$
\overline{P h(\%)=\frac{\mathrm{Phm}}{\sum_{1}^{24} \mathrm{Phm}} x 100 \quad 5}
$$

Finally, the graphs that show the spatio-temporal variability of rain with their analysis were made.

The analysis of the events was carried out by grouping different-duration events and identifying the internal characteristics of each. This allowed to understand the internal structure of the rain during events in the city of Manizales. An isolated event of rain was defined as precipitation with a magnitude and duration potentially capable of generating surface runoff and an occurrence continuous in time, without interruptions greater than 15 minutes (interruptions equal or greater than 15 minutes were considered separate events).

The temporal distribution of the rain events was analyzed considering only seven (7) of the thirteen (13) climatological stations of the network because the other stations did not contain information until 2010 (that is, Aranjuez, Emas, La Nubia, Observatory, La Palma, Posgrado and Yarumos), located at strategic points in the city. The available records analyzed were from January 2006 to July 2014, to ensure the homogeneity of the data throughout the study.

Figure 2. (Left ) Events lasting 20 minutes at the Posgrados station during 2006-2014 (Right) Dimensionless 20-minute event curves for the Posgrados station during 2006-2014

The estimation of the temporal behavior of each station was made with the rain data for each duration of the event, from which a dimensionless graph of rain versus time was obtained for all the events. As an example of the 68 rain events of 20-minute of duration recorded at the station of Posgrados (2006-2014), the accumulated precipitation is shown (see Figure 2, left) and then the same information but dimensionless (see Figure 2, right), which can allow estimating the mean values and the 90th percentile.

The values of the different percentiles were later obtained as well as the averages, such as the one obtained for the station of Posgrados (Figure 3). This same procedure was applied for rains of all durations for all network stations in Manizales.

Figure 3. Percentiles from $5 \%$ to $95 \%$ for the Posgrados station and rain events lasting 20 minutes

\section{RESULTS}


One of the predominant characteristics of the annual distribution of rainfall during the year is the bimodal regime for most of the Andean and the Caribbean region except for the Bajo Nechí region, part of the Sinú River basin and the eastern sectors slope of the Central Cordillera at the height of Samaná (Caldas); and the unimodal regime for most of the Orinoquia and the Colombian Amazon and the sectors mentioned above as exceptions in the Andean region (Arango; C., Dorado, Guzmán D, \& Ruiz, 2000; Martínez \& Salas, 2015; Poveda, 2004).

\section{Annual cycle}

Figure 4 shows the results for multi-year monthly average precipitation for the stations in the study area. This figure verifies the bimodal precipitation in each season, with two periods of intense rain and two periods of low precipitation, as previously identified for the Andean region of Colombia. The low rainy seasons correspond to the months of December to February (DJF), and June to August (JJA), while the periods of high precipitation range from March to May (MAM), and from September to November (SON). The second season of low precipitation is slightly drier than the first, with July being the month with the lowest precipitation for all rain stations. The second season of high rainfall is much more intense than the first (except in La Nubia), with November generally being the month with the highest rainfall. However, the stations of Yarumos, Emas and Chec-Uribe stations show higher rainfall in October. Regardless, the stations of La Nubia and Posgrados show very few differences between the monthly values of each winter period: rainfall is very similar in the four periods. On the contrary, stations like Chec-Uribe, Hospital and Los Yarumos show great differences between each high rainy season (over $100 \mathrm{~mm}$ ), followed by Alcazares, La Palma and Bosques.

Figure 4 . Multi-year monthly average rainfall for network stations for landslide risk management

Figure 5 shows that the stations with the highest annual and monthly rainfall are El Carmen and Yarumos, the former located to the west of the city where it tends to rain more, while the latter is located in the east where it rains a little less. As this station is located in a forest reserve, this behavior is considered atypical. These stations have a rainfall of $\sim 1800-1900 \mathrm{~mm}$, and then there is a group that oscillates in annual mean rainfall $\sim 1500 \mathrm{~mm}$ such as Emas, Alcazares located to the west, Hospital to the center and Posgrados to the south-east which is also near a reserve forest. The stations with the lowest rainfall are La Nubia and Milan Planta Niza located to the east of the city. The differences in average annual precipitation between the two stations with the highest and lowest precipitation in the analyzed period reach close to $800 \mathrm{~mm}$, which evidences the high variability in the city. Despite the small area studied, the spatial distribution shows significant variability in the monthly precipitation values due to its microclimates, already identified (Velez-upegui et al., 2012).

Regarding rainfall behavior during the analyzed period, the years 2010-2011 and 2017 were much rainier than usual (in Yarumos, Hospital de Caldas, Emas, and El Bosque in 2016 as well) especially in November (all stations). This is compatible with what was identified by the Institute of Hydrology, Meteorology and Environmental Studies in Colombia (IDEAM), which indicated that during the months of May and June of 2010 conditions close to neutrality prevailed, but that there was a rapid change in July towards the cold phase (La Nina phenomenon), month after which the Oceanic Child Index (ONI) certified the occurrence of La Nina, which lasted until May 2011. Thus, this period became one of the rainiest in the Andean region of Colombia, practically eliminating the period of least rainfall in the middle of the year and the second rainy season being one of the strongest winters in Colombia, generating numerous events triggered by the rains (landslides and floods). The stations Alcazares, Chec-Uribe, Hospital de Caldas, La Palma and Los Yarumos stand out, where rainfall anomalies came to be moderately above normal for some or both years (140-170\%), while they were slightly above normal (110-140\%) in the rest of stations (Ministerio de medio ambiente, 2011).

Figure 5. Annual monthly precipitation for network stations for landslide risk management in the period 2010-2018 
Similarly, this figure also shows that 2015 (and 2016 in the case of some stations) was drier than normal ( 50 $70 \%$ of a normal year). The El Nino phenomenon of 2015, which has been one of the most intense, began in the February-March-April quarter, when the positive temperature anomalies were $+0.5 \mathrm{oC}$. In MarchApril-May they rose to $+0.7 \mathrm{oC}$; in April-May-June, at $+0.9 \mathrm{oC}$, and reached $+1.0 \mathrm{oC}$ in the May-June-July quarter. The El Nino Phenomenon lasted until 2016 causing serious shortages, reaching critical point in January 2016 when 124 municipalities in Colombia had water shortages. Additionally, according to IDEAM, the flow of the Magdalena and Cauca rivers during this stage reached historic lows in a period of 15 years. In the case of Manizales, most of the stations had the driest December in 2015 with historical lows, followed by a January 2016 with also considerably low values. The Chec-Uribe and Emas stations were the exception, showing its lowest precipitation in February 2016. The influence of both phases of the ENSO (El Nino and La Nina) has already been previously identified and their impact on monthly variability is recognized as considerable in Colombian hydrology, an impact that even reaches diurnal and hourly scales (Poveda, 2004; Poveda et al., 2002).

When observing the behavior of precipitation taking into account the altitude (see Figure 6), a positive linear relationship between elevation and precipitation is seen. However, given the short range of amplitude in elevation, no relevant conclusions can be derived without looking at the spatial distribution in the events.

Figure 6. Relationship between annual precipitation and elevation during the period 2010-2018 for the city of Manizales

\section{Day-night cycle}

Figure 6 shows the multiannual hourly average precipitation results, which varies between $1-4.5 \mathrm{~mm} / \mathrm{h}$. A bimodal behavior of the diurnal rainfall is observed. The stations of Alcazares and Hospital have the highest hourly maximum precipitation values, while La Nubia and Posgrados show the lowest diurnal precipitation values.

The hours with the highest precipitation magnitudes are from 1:00 $\mathrm{h}$ to $4: 00 \mathrm{~h}$ and in the afternoon from 13:00 $\mathrm{h}$ to 18:00 $\mathrm{h}$. The maximum hourly rainfall occurs in the early hours of the day for all stations, peaking at 1:00 $\mathrm{h}$ and around 15:00 $\mathrm{h}$ in several stations. However, bimodal behavior is modified in the low rainfall months (DJF) where a multimodal behavior can occur in the maximum hourly rainfall, that is, several peaks throughout the day. This is how in the off-peak hours (8:00-12:00 h) during these months high hourly rainfall has occurred. On the contrary, in the months of high rainfall the bimodal behavior is observed in a very marked way, especially for the first winter season.

Figure 7 . Multiannual mean hourly rainfall for network stations for landslide risk management

Figure 8 shows the results of the relative frequency of multi-year hourly precipitation for the analyzed period, which varies between 2 and 20\%. The stations with the highest relative frequencies are Posgrados (26.7), Emas (26.3), Hospital (25.2), Yarumos (25.2), La Nubia (25.2) and Bosques (24.0), stations located in the north and center of the city. The bimodal behavior observed in the hourly precipitation magnitudes of the previous Figure is observed more precisely in this one, with two periods of 6 hours of low relative frequencies and 6 hours of high ones. The most frequent hours are from 1:00 h to 4:00 h and from 13:00 h to 16:00 h, the latter strip being the one with the highest occurrence of rain events. The hours with least frequency are from 6:00 $\mathrm{h}$ to 11:00 $\mathrm{h}$ and from 18:00 $\mathrm{h}$ to $22: 00 \mathrm{~h}$, where the former is much less frequent in rain occurrence in most stations. The second peak of high frequencies is highly concentrated between 13:00 $\mathrm{h}-16: 00 \mathrm{~h}$, while the second peak of higher precipitation magnitudes can occur until 19:00 $\mathrm{h}$.

Figure 8 . Relative frequency of multi-year hourly precipitation for each month for network stations for management of landslide risk 


\section{Temporal distribution of rain events}

A description of the events selected during the 2006-2014 period and used in this analysis is shown in Table 2 , with an average of 16.1 events per month that are distributed $2.2 \%$ of the time -that is, 1,643 events on average per season. Figure 9 shows the events for the different durations discretized, where it can be seen that the most frequent duration of rainstorms in the city varies between 20 and 55 minutes. The figure also shows that the largest number of events occur for almost all durations in El Carmen and Observatorio Vulcanologico stations located to the west of the city.

Table 2. Description of the isolated events considered for the analysis during the period 2006-2014

Figure 9 . Distribution of the durations of the events considered in the period 2006-2014

Figure 10 shows the temporal distribution of the precipitation of the stations analyzed for the $90 \%$ percentile. The distribution analysis shows that the most unfavorable temporal distribution for the design storms would be the $90 \%$ percentile, while the mean value would be a value that underestimates extreme events. Therefore, neither the 50th percentile nor the average value are taken into account in the analysis. Analyzed stations have a similar temporal distribution (this not only for the $90 \%$ percentile but for all the percentiles) showing only differences in the magnitude of precipitation as previously observed. It can also be seen that in Aranjuez, La Palma and Emas the rainfall is slightly more intense at the beginning than for the other stations.

Figure 10. Temporal distribution of rain events in the city of Manizales using 2006-2014 records for the $90 \%$ percentile

One of the most used patterns in Colombia to obtain the temporal distribution of precipitation is Huff's distribution (Huff, 1967; Huff \& Angel, 1989; Huff \& Vogel, 1976) and it is an interesting comparison to the results obtained in Manizales (see Figure 11). Figure 11 shows that the temporal distribution resembles an intermediate value between the first and second Huff quartiles, which is important since the second quartile had always been proposed for Colombia. However, for design purposes, the most unfavorable situation is always recommended to have a conservative design, so the proposal is suitable for design storms in Colombia. It is observed that $\sim 58 \%$ of the precipitations occur in $30 \%$ after the rain has passed (Table 3 ).

Figure 11. Comparison between the quartiles proposed by Huff for rainfall of $90 \%$ probability and the $90 \%$ percentile of the Posgrados station

Finally, for the design of hydraulic infrastructures and for the hydrological design in the city of Manizales, the 90th percentile of the dimensionless curve that relates duration $(\mathrm{t} / \mathrm{T})$ and total rainfall $(\mathrm{P} / \mathrm{TPP})$ is then proposed as the temporal distribution of the design storm as shown in Figure 11. The behavior for the different stations in the city is very similar. In conclusion, a temporal distribution is available for the design of rainfall in Manizales according to the distribution shown in Table 3.

Table 3. Temporal distribution of rains to be used in design events for the city of Manizales

\section{CONCLUSIONS}

Rainfall in the urban area of the city of Manizales is quite variable despite being such a small area $\left(35 \mathrm{~km}^{2}\right)$. However, there doesn't seem to be a relationship with the height of each stations and rainfall.

For all stations, bimodal behavior can be seen in the diurnal cycle and in the monthly cycle, the latter associated with the Intertropical Confluence Zone (ITCZ). In general, it is observed that the stations have monthly averages close to each other, but when their annual value is totaled, variations of up to $70 \%$ are observed between the station with the lowest rainfall (La Nubia in the east) and the one with the highest rainfall (El Carmen to the west), indicating a high spatial variability in the city.

As for the diurnal cycle, a decrease in rain is observed between 09:00 $\mathrm{h}$ and 11:00 $\mathrm{h}$ throughout the city, while the highest rains occur in the afternoon for the eastern zone stations, presumably due to the convective effect of warming during the day. Rains can also be identified in the early hours of the morning particularly in the western part of the city. 
The knowledge of the diurnal cycle of rain, of the intra-annual structure of the precipitation and of the rainstorms becomes a planning tool for the territory and a reference input for city builders. For instance, the works in the city of Manizales will be able to schedule their concrete or pavement castings at the most convenient day or month of the year to guarantee construction efficiency. Finally, the knowledge of the diurnal cycle of the rain allows to understand the dynamics of the climate in the Andean region of Colombia, which is strongly influenced by climatic variability.

Regarding the spatial distribution of rainfall, the highest rainfall occurs in El Carmen and Yarumos, the former located to the west while the latter is located to the north-east of the city in a forest reserve. Generally, it rains more to the west of the city, but there are some points of high precipitation in the center (Hospital) and east (Posgrados). Alcazares and Hospital have the highest hourly maximum precipitation values, while the stations with the lowest diurnal maximum precipitation values are La Nubia and Posgrados. Posgrados, Emas, Hospital, Yarumos, La Nubia and Bosques are the stations with the highest relative frequencies, located in the north and center of the city.

The resulting temporal distribution of the rain serves for the designers of hydraulic infrastructures to use design storm more realistically in the city of Manizales, where 20 to 30-minutes rainstorms are prevalent in the city.

Therefore, the dimensionless patterns found serve as a tool for design storms that the different hydraulic infrastructures require in the city of Manizales.

Studies that connect intra-annual, interannual and diurnal cycle variability are recommended, once information is available with a greater number of years (at least 30 years of data). This study is a basis for future researches of this kind.

\section{DATA AVAILABILITY STATEMENT}

The data that support the findings of this study are available in Caldas environmental information and data center (CDIAC because of its name in Spanish) at http://cdiac.manizales.unal.edu.co/inicio/, reference number [15]. These data were derived from the following resources available in the public domain: http://cdiac.manizales.unal.edu.co/inicio/

\section{REFERENCES}

Adams, B. J., \& Howard, C. D. D. (1986). Design Storm Pathology.Canadian Water Resources Journal , 11 (3), 49-55. https://doi.org/10.4296/cwrj1103049

Albright, M. D., Mock, D. R., Recker, E. E., \& Reed, R. J. (1981). A diagnostic study of the diurnal rainfall variation in the GATE B-scale area. Journal of Atmospheric Science, 38 , 1429-1445.

Arango; C., Dorado, J., Guzman D, \& Ruiz, J. F. (2000).Climatologia Trimestral para Colombia . Bogota D.C., Colombia.

Azli, M., \& Rao, A. R. (2010). Development of Huff curves for Peninsular Malaysia. Journal of Hydrology, 388 (1-2), 77-84. https://doi.org/10.1016/j.jhydrol.2010.04.030

Ball, J. E. (1994). The influence of storm temporal patterns on catchment response. Journal of Hydrology , $158,285-303$.

Bedoya-Soto, J. M., Aristizabal, E., Carmona, A. M., \& Poveda, G. (2019). Seasonal shift of the diurnal cycle of rainfall over Medellin's Valley, Central Andes of Colombia (1998-2005). Frontiers in Earth Science , $7,1-14$.

Chow, V., Maidment, D., \& Mays, L. (1994). Applied hidrology .Applied hidrology . McGraw-Hill.

Dai, A., Lin, X., \& Hsu, K. (2007). The frequency, intensity, and diurnal cycle of precipitation in surface and satellite observations over low- and mid-latitudes. Climate Dynamics , 29 , 727-744. 
El-Jabi, N., \& Sarraf, S. (1991). Effect of maximum rainfall position on rainfall-runoff relationship. Journal of Hydraulic Engineering , 7, 681-685.

Gray, W. M., \& Jacobson, R. W. (1977). Diurnal variation of deep cumulus convection. Monthly Weather Review , 105 (9), 1171-1188. https://doi.org/https://doi.org/10.1175/15200493(1977)105<1171:dvodcc > 2.0.co

Gui-Ying, Y., \& Slingo, J. (2001). The diurnal cycle in the tropics.Monthly Weather Review , 129 , 784-801.

Huff, F. A. (1967). Time distribution of rainfall in heavy storms. Water Resources Research , 3 (4), 10071017.

Huff, F. A., \& Angel, J. R. (1989). Frequency Distributions and Hydroclimatic Characteristics of Heavy Rainstorms in Illinois .Illinois State Water Survey Bulletin (Vol. 70).

Huff, F. A., \& Vogel, J. L. (1976). Hydrometeorology of Heavy Rainstorms in Chicago and Northeastern Illinois . Phase I - Historical Studies. Illinois State Water Survey Report of Investigation(Vol. 82).

IDEA UN Manizales, \& CORPOCALDAS. (2015). Centro de Datos e Indicadores Ambientales de Caldas (CDIAC).

Mapes, B. E., Warner, T. T., Xu, M., \& Negri, A. J. (2003a). Diurnal patterns of rainfall in northwestern South America. part III: diunal gravity waves and nocturnal convection off-shore. Monthly Weather Reviews , $131,830-844$.

Mapes, B. E., Warner, T. T., Xu, M., \& Negri, A. J. (2003b). Diurnal patterns of rainfall in nothwesten South America. part I: observations and context. Monthly Weather Reviews , 131 , 799-812.

Marin, L. M., Jimenez, J., Moreno, H. A., Velez, J. I., Guzman, J. V, \& Poveda, G. (2005). Distribucion Espacial Y Ciclo Diurno De La Temperatura Ambiente Y Punto De Rocio En Una Region De Los Andes Tropicales De Colombia. Avances En Recursos Hidraulicos , (12), 149-158.

Martinez, A., \& Salas, J. D. (2015). Modelacion estocastica de lluvias horarias. Ingenieria Del Agua , 11 (1), 29. https://doi.org/10.4995/ia.2004.2520

McGarry, M. M., \& Reed, R. J. (1978). Diurnal variations in convective activity and precipitation during phases II and III of GATE.Monthly Weather Review , 106 , 101-113.

Ministerio de medio ambiente, I. (2011). Analisis del impacto del fenomeno "La Nina" 2010-2011 en la hidroclimatologia del pais. InII Congreso nacional del clima 2011, la adaptacion en Colombia.Bogota D.C., Colombia.

Poveda, G. (2004). La hidroclimatologia de Colombia: una sintesis desde la escala inter-decadal hasta la escala diurna. Ciencias de La Tierra, 28 (107), 201-222.

Poveda, G., Mesa, L. F., Salazar, P. A., Arias, H. A., Moreno, S. C., Vieira, P. A., \& Al, E. (2005). The diurnal cycle of precipitation in the Tropical Andes of Colombia. Monthly Weather Reviews ,133 , 228-240.

Poveda, G., Mesa, O., Agudelo, P. A., Alvarez, J. F., Arias, P. A., Moreno, H. A., .. Vieira, S. C. (2002). Diagnostico del Ciclo Anual y Efectos del ENSO sobre la intensidad maxima de lluvias de duracion entre 1 y 24 horas en los Andes de Colombia. Meteorologia Colombiana, 5 (March), 67-74.

Puertas, O. L., Carvajal, Y., \& Quintero, M. (2011). Study of Monthly Rainfall Trends in the Upper and Middle Cauca River Basin, Colombia.Dyna , 169 , 112-120.

Rozante, J., Vila, D., Barboza Chiquetto, J., Fernandes, A., \& Souza Alvim, D. (2018). Evaluation of TRMM/GPM Blended Daily Products over Brazil. Remote Sensing , 10 (6), 882. https://doi.org/10.3390/rs10060882 
Singh, S. C., Hananto, N., Qin, Y., Leclerc, F., Avianto, P., Tapponnier, P. E., .. Barbot, S. (2017). The discovery of a conjugate system of faults in the Wharton Basin intraplate deformation zone. Science Advances , 3 (1), e1601689. https://doi.org/10.1126/sciadv.1601689

Singh, V. P. (1997). Effect of spatial and temporal variability in rainfall and watershed characteristics on stream flow hydrograph. Hydrological Processes , 11 , 1649-1669.

Snow, J. W. (1976). The climate of northern South America. in Climates of Central and South America. In W. Schwerdtfeger (Ed.) (pp. 295-403). Amsterdam: Elsevier.

Šraj, M., Dirnbek, L., \& Brilly, M. (2010). The influence of effective rainfall on modeled runoff hydrograph. Journal of Hydrological Hydromechanics , 58 , 3-14.

Suárez-Cobián, P. (1959). El periodo diurno en las lluvias en los Andes ecuatoriales. Revista Academia Colombiana de Ciencias , $X$, 327-335.

Trewartha, G. T. (1981). The earth's problem climates . Madison: University of Wisconsin Press.

Trojer, H. (1959). Fundamentos para una zonificación meteorológica y climatológica en el trópico y especialmente en Colombia.Seminarios Cenicafé , 10 , 289-373.

Vélez-Upegui, J. J., Duque-Méndez, N. D., Mejía-Fernández, F., \& Orozco-Alzate, M. (2012). Red de monitoreo Climatico para dar apoyo a la prevención y atención de desastres en Manizales, Colombia, (January 2015), 12.

Zuluaga, I. C. M., Poveda, G., \& Mejia, J. F. (2004). Ciclo Diurno de la Precipitación sobre Colombia y el Pacífico Oriental durante 1998-2002 según la misión TRMM. XVI Seminario Nacional de Hidráulica e Hidrología .

\section{Hosted file}

Table 1.docx available at https://authorea.com/users/320360/articles/449966-the-knowledgeof-the-spatial-temporal-rainfall-patterns-as-a-tool-for-storm-design-case-studymanizales-colombia

\section{Hosted file}

Table 2.docx available at https://authorea.com/users/320360/articles/449966-the-knowledgeof-the-spatial-temporal-rainfall-patterns-as-a-tool-for-storm-design-case-studymanizales-colombia

\section{Hosted file}

Table 3.docx available at https://authorea.com/users/320360/articles/449966-the-knowledgeof-the-spatial-temporal-rainfall-patterns-as-a-tool-for-storm-design-case-studymanizales-colombia 

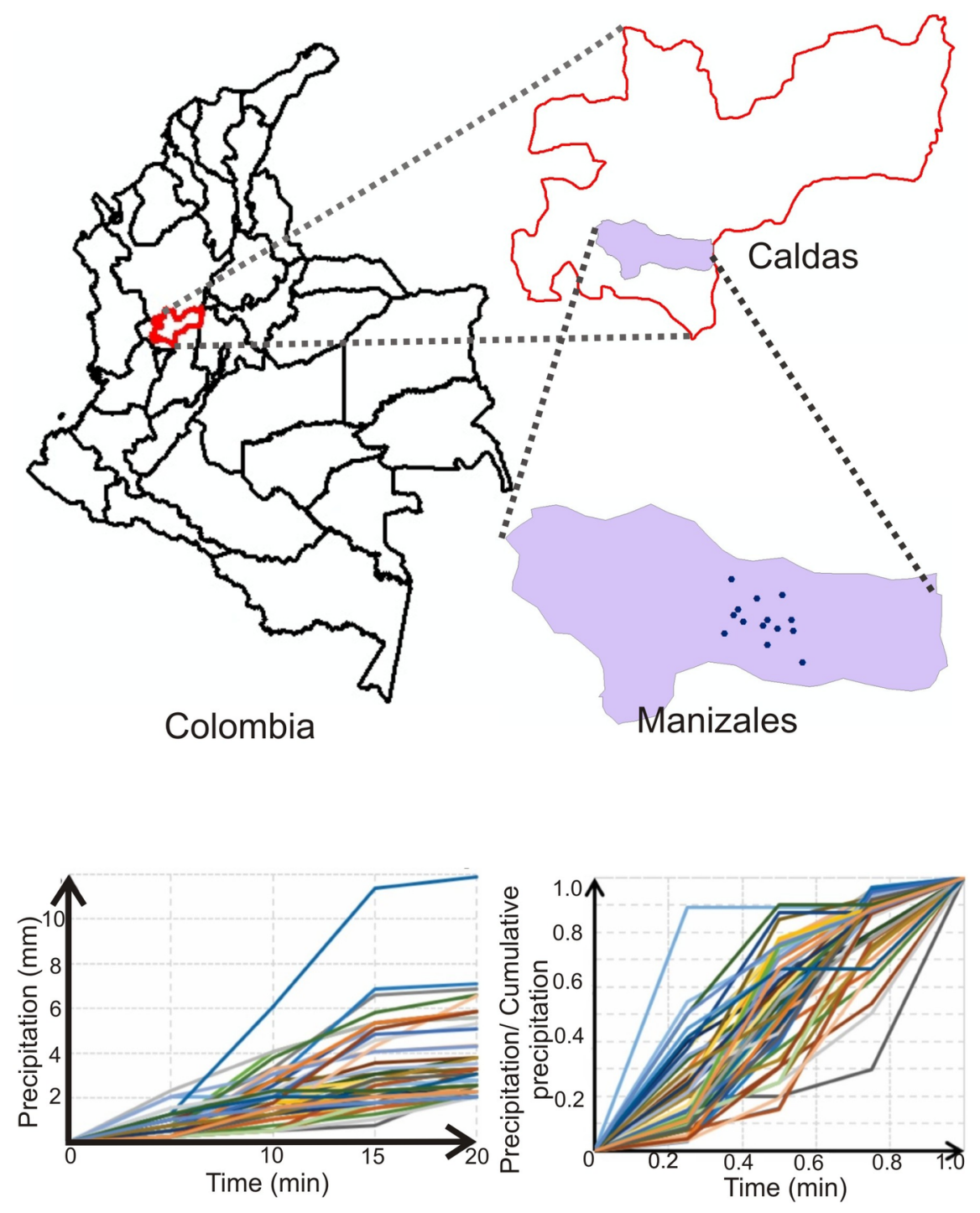

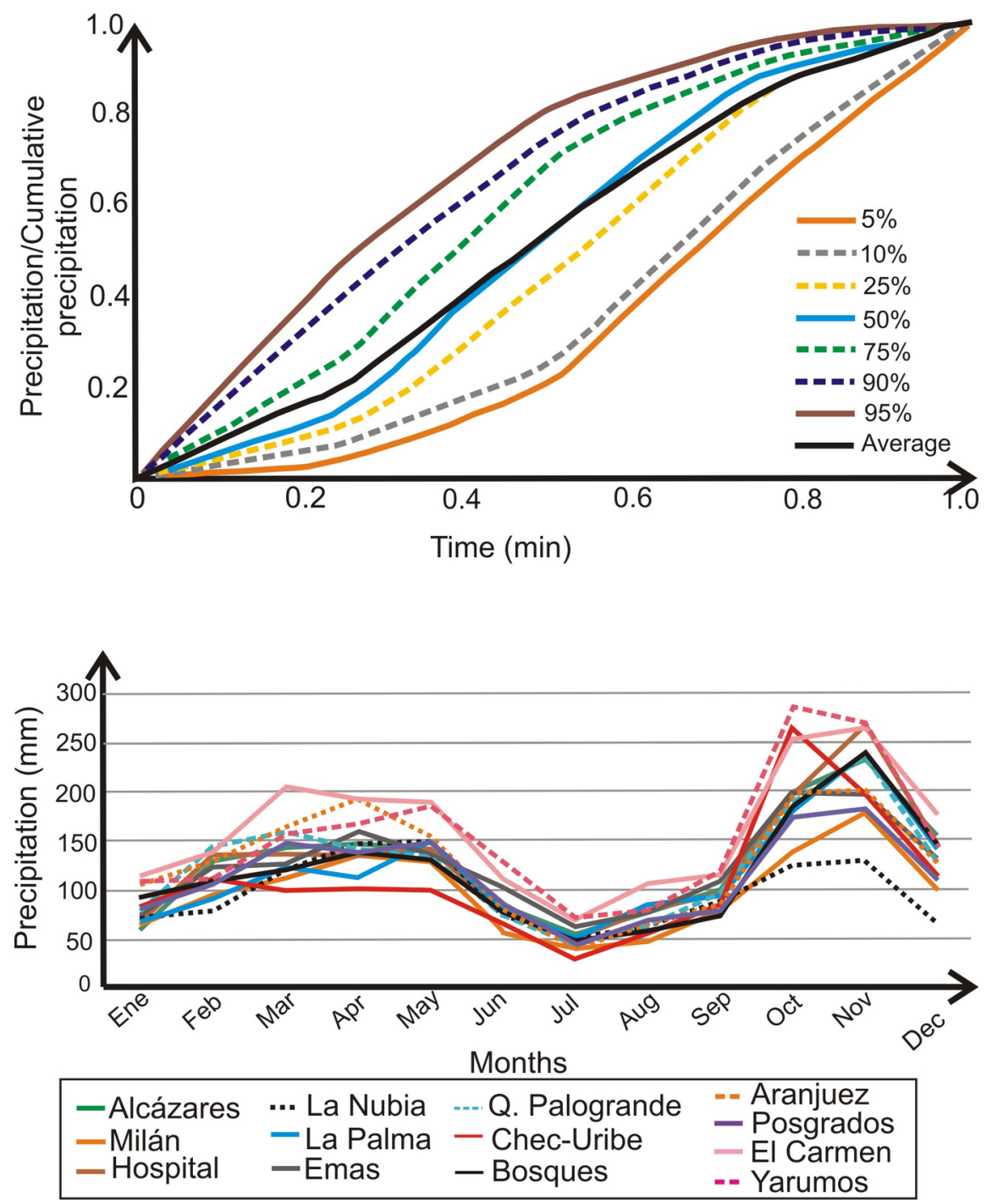

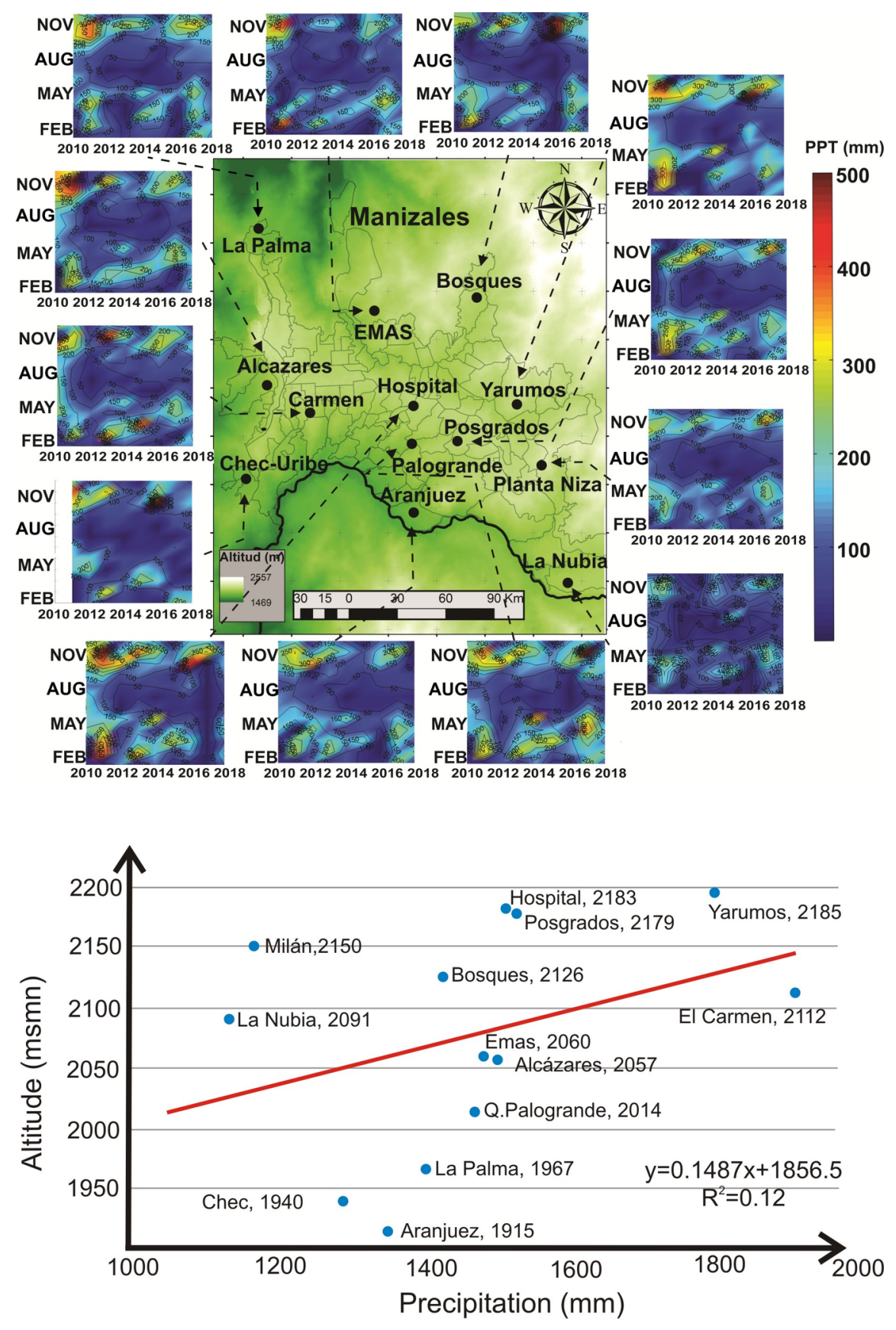


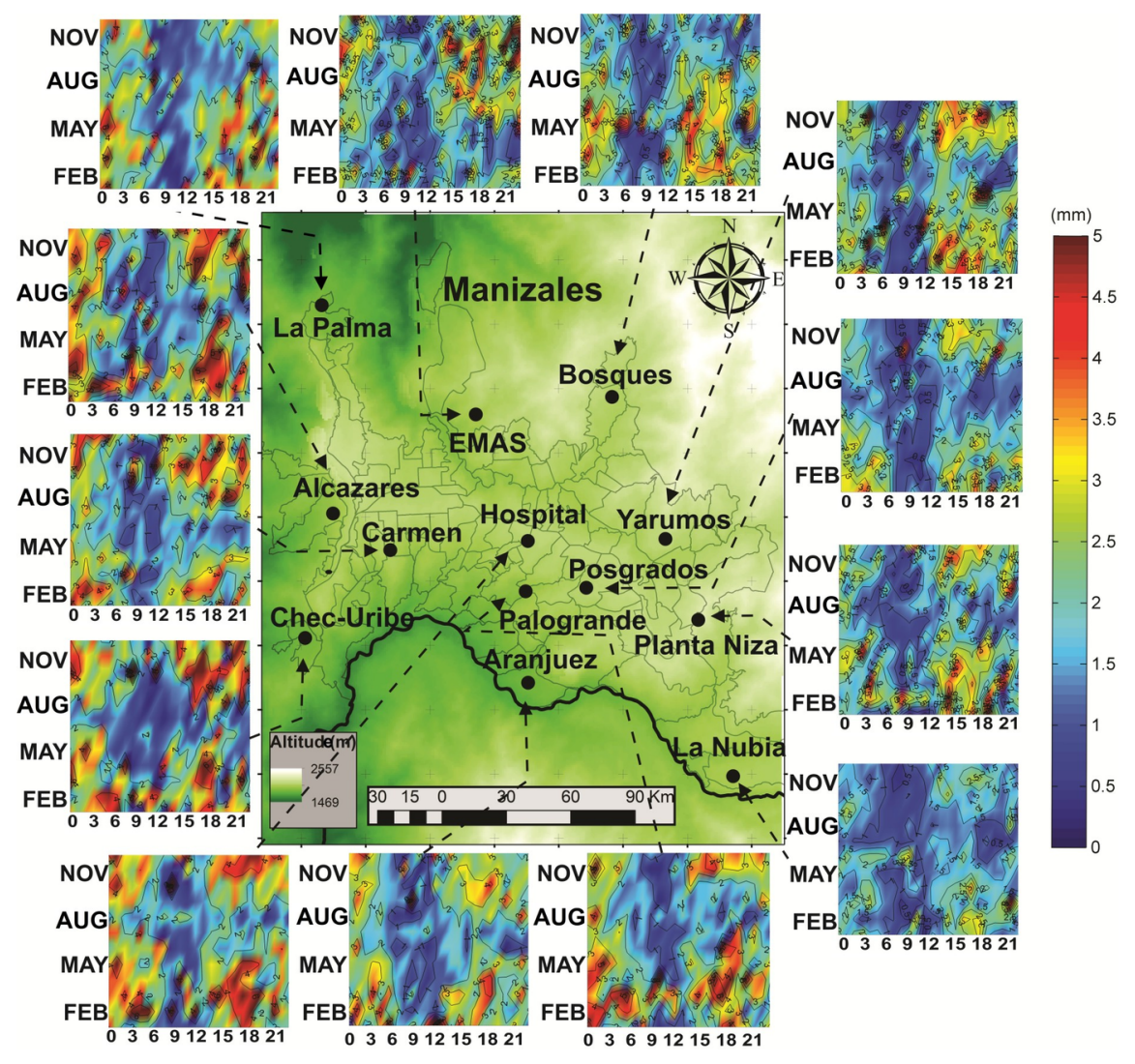



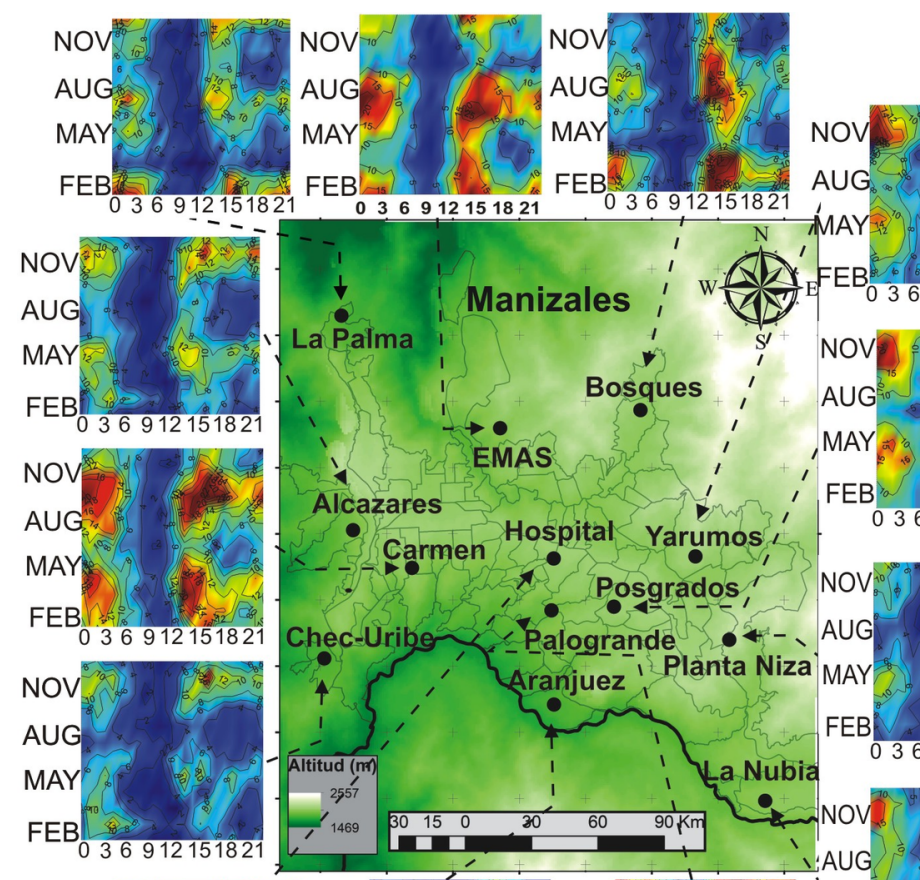

MAY


Carmen Hospital Yarumos '

Posgrados,

Chec-Uribor - Palogrande

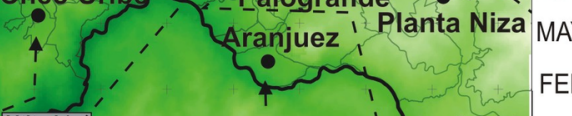

FEB
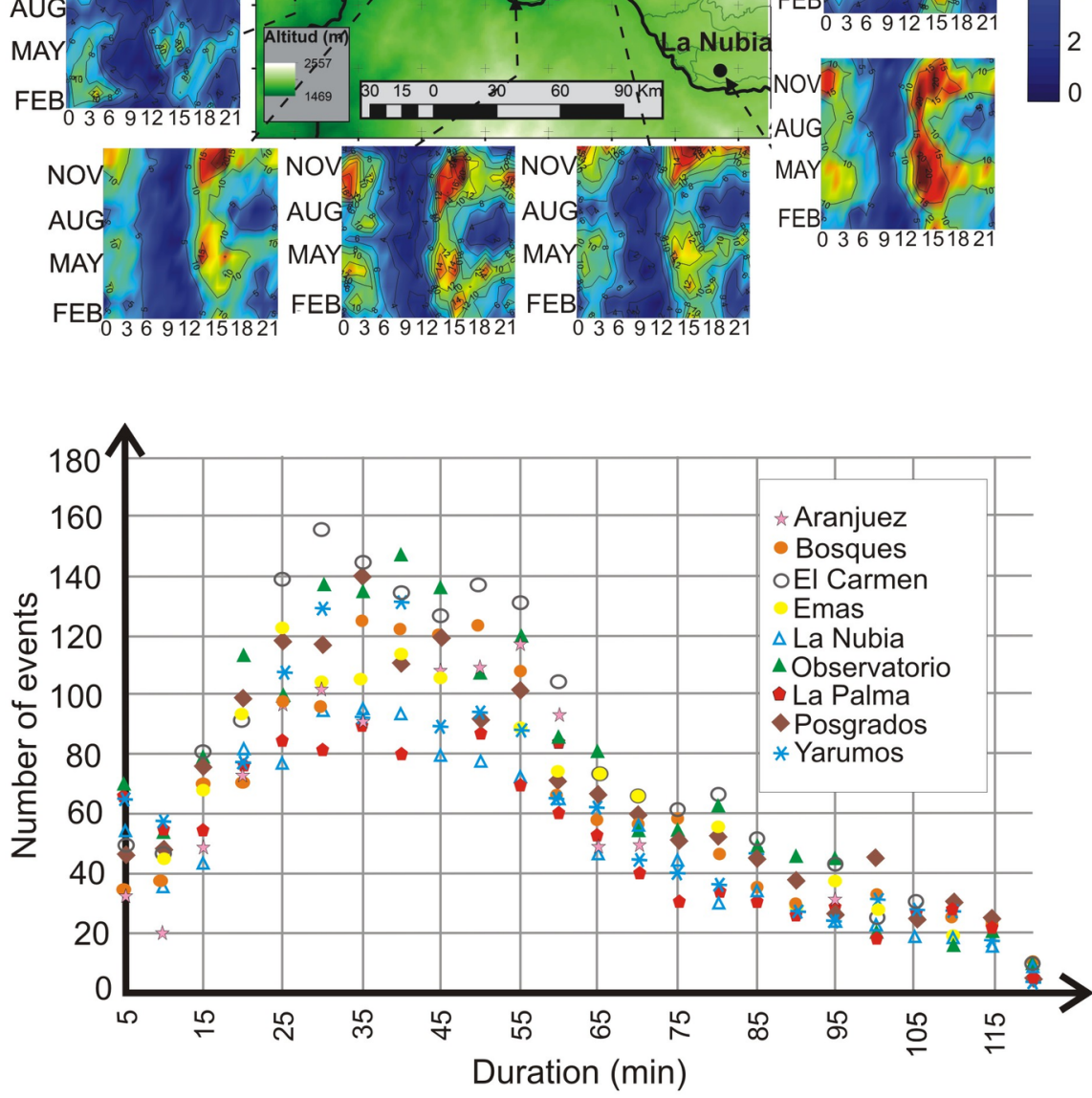

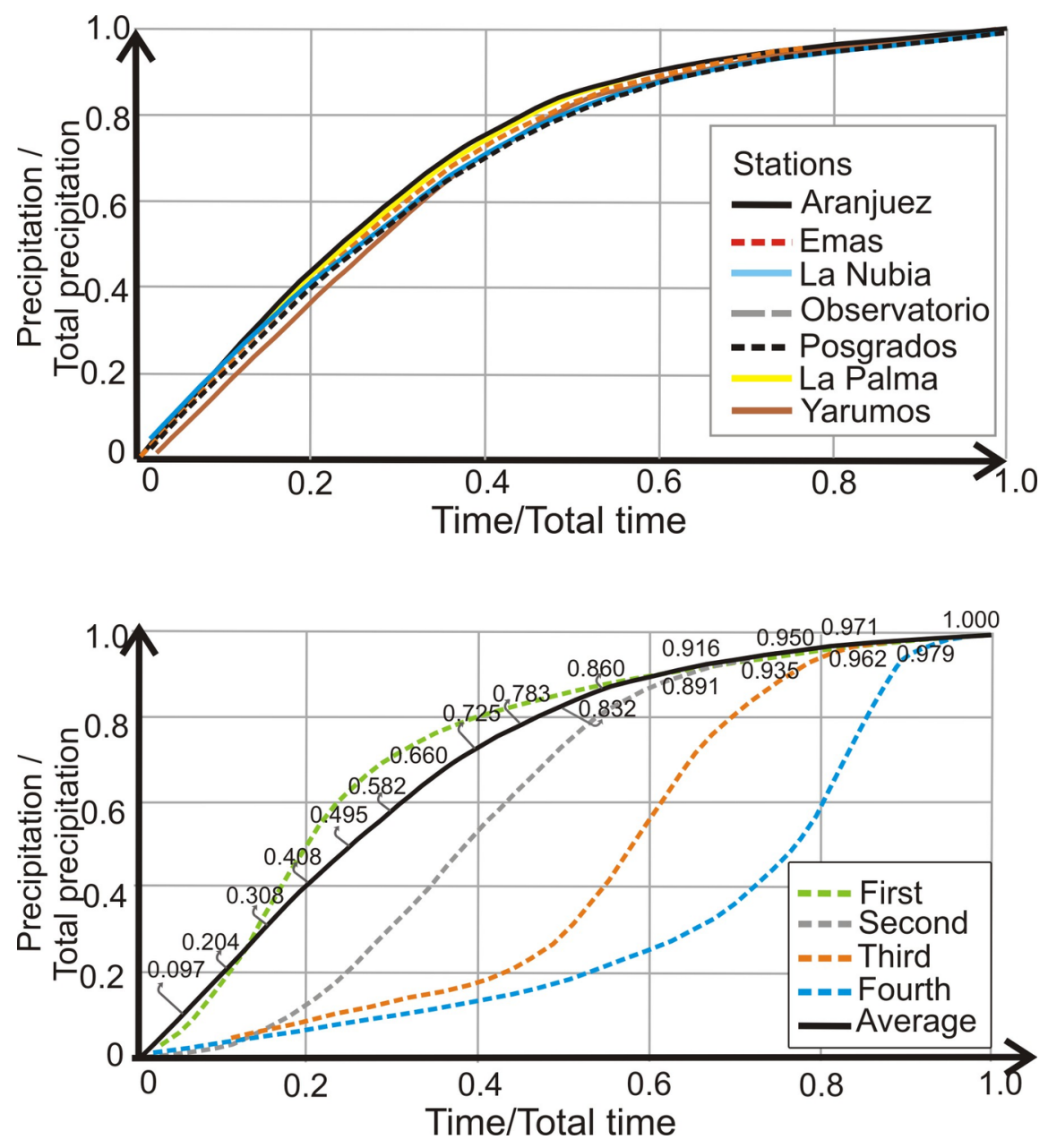